\title{
GONADAL AND EXTRAGONADAL SPERM RESERVES OF INDIGENOUS CENTRAL AFRICAN BULLS
}

\author{
G. IGBOELI AND A. M. RAKHA \\ National Council for Scientific Research, \\ P.O. Box 49, Chilanga, Lusaka
}

(Received 2nd September 1970)

The relationship between testis size, sperm reserves, ejaculate volume and sperm concentration are well established, (Ortavant, 1956; Almquist, Amann \& O'Dell, 1958; Hale \& Almquist, 1960; Hahn, Foote \& Seidel, 1969). In a another report, Igboeli \& Rakha (1971) showed that the ejaculate volume and the number of spermatozoa per ejaculate of mature Angoni bulls (Central African Zebu) are less than those values reported for breeds from more temperate areas. No previous reports appear to be available on the testis size, and gonadal and extra-gonadal sperm reserves of indigenous Central African bulls.

Thirty, sexually mature, indigenous breeding bulls-ten Africander, ten Angoni, and ten Barotse-were slaughtered, and the reproductive organs were removed. The left and right testes and epididymides were trimmed and weighed. After careful removal of the tunica albuginea, each testis was homogenized at $6000 \mathrm{rev} / \mathrm{min}$ for $2 \mathrm{~min}$. After recording the homogenate volume, a sample of the homogenate was diluted 1:40 v/v using physiological saline containing antibiotics. The caput, corpus, and cauda of the epididymis were minced separately with sharp pointed scissors in individual beakers containing $20 \mathrm{ml}$ of physiological saline and the volume was noted. The suspensions were then strained through two layers of sterile cheese-cloth into graduated test tubes. All samples were then stored for $24 \mathrm{hr}$ at $5^{\circ} \mathrm{C}$ before diluting and counting in the haemocytometer. The gonadal sperm reserve was estimated as the total number of late spermatids and spermatozoa in the homogenized testicular tissue.

Data were subjected to standard statistical analysis. The results are summarized in Table 1.

The testicular weights of Barotse bulls $(140 \mathrm{~g})$ were statistically significantly smaller than those of either the Africander $(190 \mathrm{~g})$ or the Angoni $(200 \mathrm{~g})$ breeds, which in turn, did not differ significantly $(P>0.05)$. The epididymal weights were comparable in all three breeds but were smaller than values reported for breeds in more temperate regions (Igboeli \& Foote, 1968).

When the regression formula devised by Willett \& Ohms (1957) for the estimation of testicular weight using scrotal circumference was applied to the dimensions obtained from Angoni bulls (mean scrotal circumference $31.9 \mathrm{~cm}$ ), it was found that the weights were over-estimated. A similar formula by Hahn et al. (1969) tended to give an under-estimate. These findings emphasize the need for a detailed study to determine the ratio of spermatogenic tissue to total 
testicular area as well as variations in the thickness of the scrotal skin of local bulls.

Igboeli \& Rakha (1971) reported a mean sperm concentration of $5.60 \times 10^{9}$ cells/ejaculate for the Angoni bulls. If it is assumed that most of the spermatozoa in an ejaculate come from the cauda epididymidis, it would appear that the sperm reserves in the caudae of these bulls are only adequate for two to three successive ejaculations and are much less than the sperm reserves reported for bulls from more temperate regions (Hale \& Almquist, 1960).

\section{TABLE 1}

GONADAL AND EXTRA-GONADAL SPERM RESERVES OF INDIGENOUS AFRIGAN BULLS

\begin{tabular}{|c|c|c|c|c|c|c|c|c|}
\hline \multirow{3}{*}{ Breed } & \multicolumn{4}{|c|}{ Weights $(g)$} & \multicolumn{4}{|c|}{ Sperm reserves $\left(\times 10^{9}\right)^{*}$} \\
\hline & \multirow[b]{2}{*}{ Testis } & \multicolumn{3}{|c|}{ Epididymis } & \multirow[b]{2}{*}{ Testis } & \multicolumn{3}{|c|}{ Epididymis } \\
\hline & & Caput & Corpus & Cauda & & Caput & Corpus & Cauda \\
\hline $\begin{array}{l}\text { Africander } \\
(10)\end{array}$ & $\begin{array}{r}190 \cdot 8 \\
\pm 13.4\end{array}$ & $\begin{array}{r}12.90 \\
\pm 1 \cdot 79\end{array}$ & $\begin{array}{r}3.80 \\
+0.65\end{array}$ & $\begin{array}{r}7.84 \\
\pm 2.61\end{array}$ & $\begin{array}{r}23.78 \\
\pm 6.79\end{array}$ & $\begin{array}{r}2.57 \\
\pm 0.36\end{array}$ & $\begin{array}{r}0.53 \\
\pm 0.09\end{array}$ & $\begin{array}{r}9.33 \\
\pm 1.35\end{array}$ \\
\hline $\begin{array}{c}\text { Angoni } \\
\text { (10) }\end{array}$ & $\begin{array}{r}200 \cdot 3 \\
\pm 25 \cdot 5\end{array}$ & $\begin{array}{r}11 \cdot 50 \\
\pm 2 \cdot 17\end{array}$ & $\begin{array}{r}2.89 \\
\pm 0.50\end{array}$ & $\begin{array}{r}8 \cdot 18 \\
\pm 2 \cdot 65\end{array}$ & $\begin{array}{r}19.57 \\
\pm 8.28\end{array}$ & $\begin{array}{r}3.52 \\
\pm 0.82\end{array}$ & $\begin{array}{r}1.36 \\
\pm 0.59\end{array}$ & $\begin{array}{r}10.96 \\
\pm 1.49\end{array}$ \\
\hline $\begin{array}{c}\text { Barotse } \\
\quad(10)\end{array}$ & $\begin{array}{r}140.4 \\
\pm 15.2\end{array}$ & $\begin{array}{r}9.79 \\
\pm 0.80\end{array}$ & $\begin{array}{r}2.71 \\
\pm 0.38\end{array}$ & $\begin{array}{r}6.59 \\
\pm 0.72\end{array}$ & $\begin{array}{r}20.41 \\
\pm 4.04\end{array}$ & $\begin{array}{r}1.93 \\
\pm 0.21\end{array}$ & $\begin{array}{r}0.42 \\
\pm 0.08\end{array}$ & $\begin{array}{r}6.99 \\
+1.31\end{array}$ \\
\hline
\end{tabular}

* Refers to total sperm reserves of both left and right sides.

No. of bulls in parentheses.

With regard to the overall distribution of spermatozoa in the various zones of the epididymis, $21.3 \%$ of the total extra-gonadal sperm reserve were found in the caput, $6.1 \%$ in the corpus, and $72.6 \%$ in the cauda epididymidis. Corresponding percentages reported for breeds from temperate areas were 36.24 , 18.34 and 45.42 (Bialy \& Smith, 1959). Apart from the possibility of breed differences in the distribution of spermatozoa, there may be differences due to the efficiency of flushing (Bialy \& Smith, 1959) and mincing (Igboeli \& Foote, 1968), as methods of sperm removal from the different zones of the epididymis.

From the present results, a detailed study of spermatogenesis, sperm transport, sperm resorption and related phenomena in local Central African bulls would seem to be essential.

The authors wish to express their thanks to Mr A. C. D. Bayvel, Veterinary Officer, Livingstone, for his co-operation, and to the late $\mathrm{Mr} \mathrm{J}$. Nguluwe, $\mathrm{Mr} \mathrm{Y}$. Kapyanga and $\mathrm{Mr} \mathrm{S}$. Chilinda for their technical assistance.

\section{REFERENCES}

Almquist, J. O., Amann, R. P. \& O'Dexl, W. T. (1958) Sperm reserves of dairy bulls as determined by depletion trials and post-slaughter counts. F. Dairy Sci. 41, 733.

BiALY, G. \& SMtTh, V. R. (1959) Number of spermatozoa in the different parts of the reproductive tract of the bull. 7. Dairy Sci. 41, 1781.

HAHN, J., Foote, R. H. \& SeIDEL, G. E., JR (1969) Testicular growth and related sperm output in dairy bulls. F. Anim. Sci. 29, 41. 
HALe, E. B. \& AlwQuns, J. O. (1960) Relation of sexual behaviour to germ cell output in farm animals. 7. Dairy Sci. (Suppl.), 43, 145.

IgBorl, G. \& Foote, R. H. (1968) Maturation changes in bull epididymal spermatozoa. F. Dairy Sci. 41, 1703.

Iosorl, G. \& RAkra, A. M. (1971) Ejaculation and ejaculate characteristics of Angoni (Short horn Zebu) bulls. F. Reprod. Fort. 26. (In press).

Ortavanr, R. (1956) Spermatogendae et reserves spermatiques chez le taureau et le belier. IIIrd Int. Congr. Anim. Roprod. Cambridge.

WirletT, E. L. \& Orms, J. I. (1957) Measurement of testicular size and its relation to production of spermatozoa by bulls. J. Dairy Sei. 41, 1559. 